\title{
Mesenchymal stem cells as all-round supporters in a normal and neoplastic microenvironment
}

\author{
Ralf Hass ${ }^{*}$ and Anna Otte
}

\begin{abstract}
Mesenchymal stem cells (MSC) represent a heterogeneous population exhibiting stem cell-like properties which are distributed almost ubiquitously among perivascular niches of various human tissues and organs. Organismal requirements such as tissue damage determine interdisciplinary functions of resident MSC including self-renewal, migration and differentiation, whereby MSC support local tissue repair, angiogenesis and concomitant immunomodulation. However, growth of tumor cells and invasion also causes local tissue damage and injury which subsequently activates repair mechanisms and consequently, attracts MSC. Thereby, MSC exhibit a tissue-specific functional biodiversity which is mediated by direct cell-to-cell communication via adhesion molecule signaling and by a tightly regulated exchange of a multifactorial panel of cytokines, exosomes, and micro RNAs. Such interactions determine either tumor-promoting or tumor-inhibitory support by MSC. Moreover, fusion with necrotic/apoptotic tumor cell bodies contributes to re-program MSC into an aberrant phenotype also suggesting that tumor tissue in general represents different types of neoplastic cell populations including tumor-associated stem cell-like cells. The present work summarizes some functional characteristics and biodiversity of MSC and highlights certain controversial interactions with normal and tumorigenic cell populations, including associated modulations within the MSC microenvironment.
\end{abstract}

Keywords: Mesenchymal stem cells, Tumor cells, Microenvironment

\section{Mesenchymal stromal/stem cells represent a heterogeneous population in nearly all kinds of tissues}

Mesenchymal stem cells (MSC) can be identified in and isolated from nearly all kinds of human tissues. MSC are often synonymously termed stromal cells while other reports distinguish MSC as a precursor of stromal cells. As firstly described, bone marrow-derived human MSC (BM-hMSC) still represent the most frequently investigated hMSC population to compare their properties to those of other tissue-originating hMSC populations [1]. Among these are hMSC from adipose tissue [2], peripheral blood [3], heart [4], and lung [5] but more recently, special attention was also given to hMSC obtained from a variety of different neonatal tissues. These post-natal tissues represent a useful ethically non-controversial alternative providing certain advantages as a consistent

\footnotetext{
* Correspondence: hass.ralf@mh-hannover.de

Biochemistry and Tumor Biology Lab, Gynecology Research Unit, Department of Obstetrics and Gynecology (OE 6410), Medical University Hannover, Carl-Neuberg-Str. 1, 30625 Hannover, Germany
}

and enriched MSC source which is easily accessible. These tissues include MSC from the amniotic fluid [6], amniotic membrane [7-9], chorionic membrane [10], chorionic villi [11], decidua [10], whole placenta [12,13], cord blood [14], Wharton's jelly [15] and whole umbilical cord (UC-MSC) [16].

\section{Proliferative capacity of MSC}

The hMSC originating from different human tissues or organs are designated as stem/stromal or stem-like cells since they share functional properties such as continuous cell cycle progression and plasticity by the capability to differentiate at least along the mesodermal lineage. However, several tissue-originating MSC display significant differences in their proliferative capacities. According to the tissue-specific microenvironment of the diverse MSC populations, UC-MSC exhibit a higher proliferation potential than BM-MSC [17-19]. Thus, the mean doubling time of the UC-MSC revealed about $24 \mathrm{~h}$ and remained almost constant for up to 10 cell passages. In contrast, the population doubling time of BM- 
MSC reached approximately $40 \mathrm{~h}$ and considerably increased already after 6 cell passages [20]. Likewise, adipose tissue-derived MSC also demonstrated an elevated growth rate as compared to BM-MSC [21]. Morphological evaluations revealed a larger BM-MSC size in contrast to adipose tissue-derived MSC which was also accompanied by an earlier in vitro senescence of BMMSC [22]. However, the in vitro results of MSC may dramatically differ from the in vivo situation. In this context, effects of the cellular microenvironment such as oxidative stress and DNA damage clearly influence the proliferative capacity and premature aging of the cells [23]. Indeed, hMSC demonstrate enhanced proliferative potential in a hypoxic microenvironment which is also paralleled by an altered energy-consuming metabolism [24].

\section{Differentiation capacity and markers of MSC}

With respect to differentiation capacity, previous work has demonstrated that MSC can acquire certain functions associated with adipogenic, chondrogenic or osteogenic maturation [25-27]. This differentiation potential of MSC supports local tissue-specific precursor cells of damaged organs, since the amount of these precursor cells to retrodifferentiate to a more undifferentiated phenotype is often insufficient to cope with the cell replacement requirements of the injured tissues [28,29]. Some reports suggested the capability of distinct MSC populations to differentiate along cell lineages of all three germ layers as described for amniotic fluid-derived hMSC and for a certain clonal subpopulation of decidual-derived hMSC $[6,30]$. However, a trans-germ line differentiation via ectodermal or endodermal lineages including maturation into hepatocytes, cardiomyocyte or neuronal phenotypes remains controversial [31]. Nevertheless, the initially tissue- or organ-derived cells harbor a heterogeneous population of mesenchymal stromal cells with stem cell-like properties since a variety of distinct subpopulations can be isolated from such an entity by centrifugal counter flow elutriation. These isolated MSC subpopulations exhibit different growth rates and aging properties by quantification of senescenceassociated $\beta$-galactosidase expression $[32,33]$. This kind of heterogeneity may also explain differences in the activation status and alterations in cell biological properties and functions within the same hMSC population. According to this cellular diversity, a panel of multiple markers is required for the characterization of mesenchymal stem cells. Minimal criteria for all hMSC populations have been defined by the International Society for Cellular Therapy to characterize multipotent mesenchymal stem cells which include the capacity to plastic adherence, differentiation potential (at least osteogenic, chondrogenic and adipogenic) and expression of the cell surface markers CD73, CD90 and CD105 [34]. In addition to the necessity of these three surface molecules on hMSC, further criteria require the simultaneous absence of a variety of other specific markers including the monocytic CD14, the endothelial CD31, the hematopoietic stem cell marker CD34 and the lymphocyte CD45 surface antigen [3].

Although hMSC have a common minimal expression marker profile of surface receptors, additional distinct surface molecules and metabolic alterations can be detected between different hMSC populations which may determine their functional diversity within the different tissues. For example, umbilical cord-derived (UC) hMSC and some adipose tissue-derived MSC express significant levels of CD44 in contrast to bone-marrowderived (BM) hMSC. However, there are controversial reports on CD44 expression in BM-hMSC which suggested that the original BM-hMSC represent the CD44phenotype whereby CD44 expression is acquired in the course of in vitro culture of BM-hMSC [32,35]. The CD44 surface molecule is also termed as hyaluronan receptor which consists of several splice variants and binds supramolecular structures of highly sulfated proteoglycans, enabling a link of several protein components in close vicinity. Certain matrix-metalloproteinases (MMPs) can associate with distinct isoforms of the transmembrane glycoprotein CD44 which anchors the proteinase to the cell surface. This CD44-MMP association mediates reorganization of distinct extracellular matrix (ECM) components or contributes to focus the proteinase activities e.g. towards growth factor activation such as cleavage of pro-heparan-binding epidermal growth factor (pro HB-EGF) for the generation of soluble active sHBEGF [36]. A similar formation of this ternary growth factor complex is also observed in young human mammary epithelial cells in contrast to their aging counterparts and derailed signaling in this pathway can contribute to aging-associated breast cancer development [37-40]. Therefore, specific functions of CD44 appear to be important for MSC functions in the highly enriched glucose-aminoglycan environment of the umbilical cord or the adipogenic breast tissue but to lesser extend in the bone marrow.

Further markers are proposed for MSC which characterize at least a certain MSC subpopulation. Such markers include Stro-1 identified in BM-MSC [41]. The Stro- $1^{+}$BM-MSC can inhibit lymphocyte proliferation [42], although Stro-1 expression has also been reported in a small population of CD34 $4^{+}$hematopoietic stem cells and endothelial cells [43]. Moreover, vascular cell adhesion molecule-1 (VCAM-1, CD106), a member of the immunoglobulin superfamily which binds to the leukocyte integrins VLA-4 and $\alpha 4 \beta 7$ as well as intercellular adhesion molecule-1 (ICAM-1) are also markers associated with MSC [44]. Furthermore, nestin has been 
identified in MSC which represents an intermediate filament usually expressed in neuronal (progenitor) cells. Nestin-expressing MSC are predominantly found in the bone marrow and play an important role in the maintenance of a hematopoietic stem cell (HSC) niche and control of HSC homeostasis [45] (Figure 1). Whereas nestin is associated with cell division, proliferation and morphological changes, recent findings suggested that nestin-expressing BM-MSC can differentiate into neural cells upon exposure to an appropriate culture microenvironment [46].

Together, the minimal characteristics of surface markers still appear to be insufficient for defining the precise role of MSC and additional markers will be required for determining tissue-specificity, a selective MSC subpopulation, and the activation status of MSC.

\section{Interaction of mesenchymal stromal/stem cells and functional involvement in tissue repair, stem cell homing and angiogenesis}

A functional heterogeneity of MSC within different tissue origins appears obvious and additionally, there are also increasing evidences for functional alterations of MSC originating from the same population [32]. These effects are associated with the special microenvironment surrounding each cell which is established by individual cell-to-cell attachments and intercellular communication processes mediated by diverse interactions with different
ECM components and by the release of cytokines or the local exchange of microRNAs and membranous micro vesicles [47-49] (Figure 1, Figure 2). An uptake of these biological materials significantly influences regulatory pathways within the corresponding MSC metabolism. Indeed, MSC can exchange micro vesicles - also termed exosomes - which can contain certain pre-microRNAs [50]. MicroRNAs (miRs) represent small non-coding RNAs of about 20 to 22 nucleotides, which, upon sequence-specific binding to appropriate mRNAs, repress the translation of the corresponding proteins or induce a subsequent degradation of the miR/mRNA complexes.

\section{Functionality of miRs in MSC}

Released miR-containing exosomes into the extracellular compartment can fuse with adjacent cell membranes as a tool for intercellular communications and thereby, alter cell activities in target cells. The exchange of miRs between neighboring cells represents an integral part of MSC communication with injured cells of damaged tissue. During tissue repair and wound healing such exosomal transport allows a bidirectional exchange of miRs between injured cells and MSC. The exchange of such regulatory compounds also contributes to reprogram the phenotype of MSC to adapt to features of the damaged tissues [51]. Different miRs have been proposed to play an important role in reprogramming MSC but also in

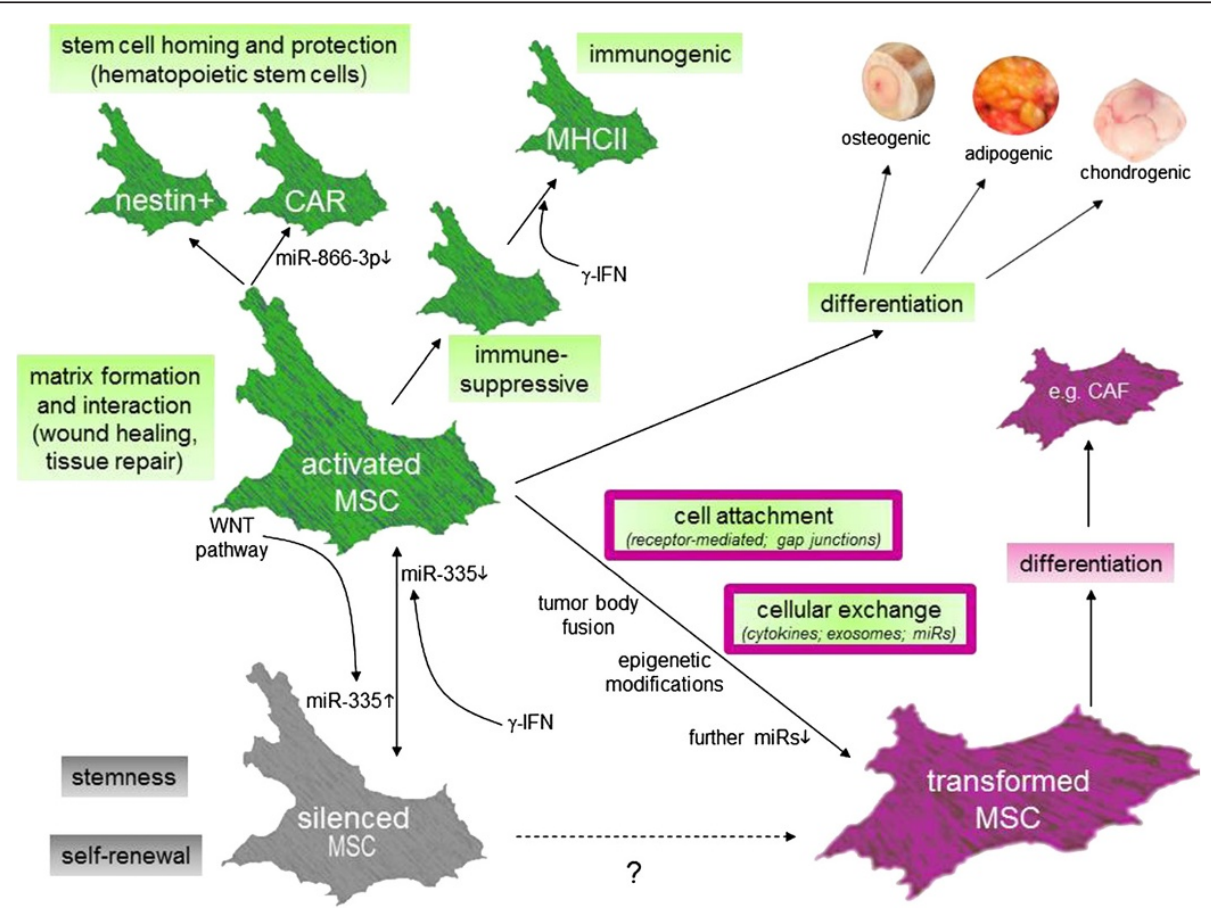

Figure 1 MSC functions, activation status-dependent interaction levels of MSC and susceptibility to transform to an aberrant MSC phenotype following acquisition of tumorigenic compounds (DAMPs or apoptotic bodies). (CAR = related stromal-derived factor-1 (SDF-1)abundant reticular cells; CAF = cancer-associated fibroblast. 


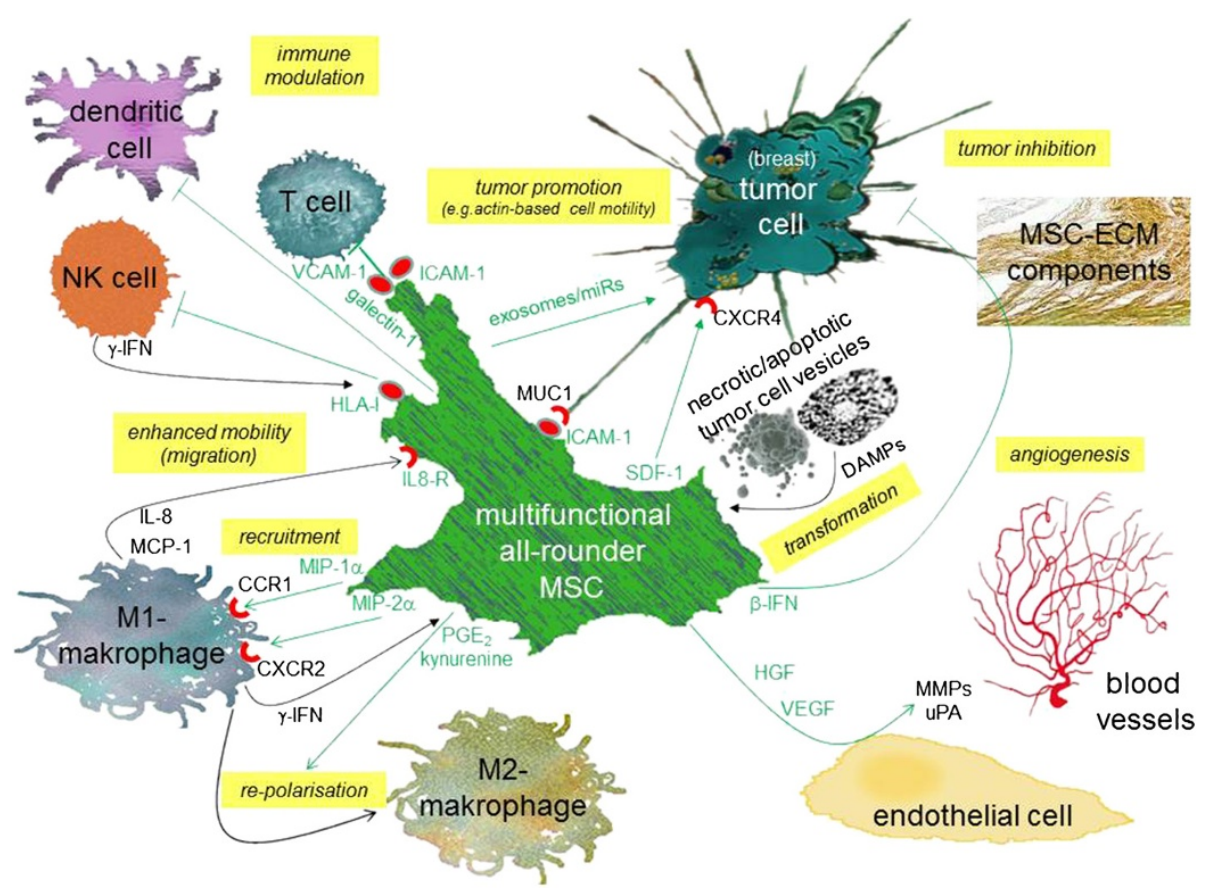

Figure 2 Interactions of activated MSC with surrounding immune cells (T cells, NK cells, dendritic cells, macrophages), endothelial cells with concomitant angiogenesis and neo-vascularisation, extracellular matrix (ECM) components, tumor cells (e.g. breast cancer cells) as well as damage-associated molecular patterns (DAMPs) and apoptotic bodies from necrotic/apoptotic tumor cell vesilces.

blocking differentiation pathways and regulating cell fate of MSC [52]. For instance, adipogenic differentiation was highly increased by miR105 and miR371 which was accompanied by respective gene expression changes of certain adipogenic key molecules including adiponectin and fatty acid-binding protein 4 . Conversely, adipogenic differentiation of MSC can be impaired by miR-369-5p [53]. Moreover, osteogenic differentiation of MSC can be inhibited by miR-125b, miR-133, miR-135 and miR-206 which attenuate the expression of ERBB2 as one of the epidermal growth factor receptors, RUNX2 (Runtrelated transcription factor 2) essential for osteoblast differentiation and skeletal morphogenesis, Smad5 as a signaling modulator of bone morphogenic proteins, and connexin-43 as a transmembrane protein and part of gap junctions, respectively. Likewise, expression of further specific miRs which contribute to the regulation of chondrogenic differentiation and pathways beyond the mesodermal lineage interfere with the corresponding functional alteration of MSC [52] (Figure 1).

Moreover, miRs are also involved in directing the role of MSC in stem cells homing, particularly in keeping the homeostasis of hematopoietic stem cells. In particular, nestin-positive MSC and their related stromal-derived factor-1 (SDF-1)-abundant reticular (CAR) cells contribute to hematopoietic stem cell functions within the endo-osteal and the perivascular niche of the bone marrow. The chemokine SDF-1 (CXCL12) which is produced and released by CAR cells represents one of the key players for cell migration in several tissues and for homing of hematopoietic stem cells to the appropriate bone marrow niches [54]. The capability of CAR cells for SDF-1 production and release is strongly associated with a constitutive down-modulation of miR-886$3 p$ in the cells since this miR specifically targets the 3 ' untranslated region of the SDF-1 mRNA. Furthermore, transfection of miR-886-3p into CAR cells results in the loss of SDF-1-mediated chemotaxis [55] (Figure 1, Figure 2).

\section{MSC interaction with macrophages}

Further MSC activities in addition to the exchange of miRs and other exosome-containing compounds include the mutual release of chemokines and cytokines between MSC and target cells during wound healing. For the repair of damaged tissues, MSC interact with macrophages that infiltrate the wound bed in injured epithelia. During this process MSC can secrete factors such as MIP1 $\alpha$ ((macrophage inflammatory protein 1-alpha), CCL3)), and MIP2 $\alpha$ ((macrophage inflammatory protein 2-alpha), CXCL2, GRO $\beta$ (Growth-regulated protein beta)) which attracts pro-inflammatory M1 macrophages via their corresponding chemokine receptors CCR1 and CXCR2, respectively, to exhibit antimicrobial activities [56,57] (Figure 2). Vice versa, M1 macrophages release a panel of factors including $\gamma$-IFN, MCP-1 ((monocyte chemotactic protein-1), CCL2)) and IL-8 which increases the mobility 
of MSC [58]. To balance this inflammatory response, MSC can also repolarize these macrophages into antiinflammatory M2 macrophages. This is mediated by $\gamma$-IFN-induced expression of cyclooxygenase in MSC followed by enhanced production and secretion of $\mathrm{PGE}_{2}$, whereby the MSC-mediated local increase in prostaglandin concentration contributes to silence the macrophage inflammatory activity. Similarly, indoleamine 2,3-dioxygenase which is also inducible in MSC by $\gamma$-IFN, catalyzes the conversion from tryptophan to kynurenine and tryptophan depletion in the cellular microenvironment inhibits the immune cell activity [59-61]. This refunctioning of macrophages by MSC as proposed in a model [57] further promotes wound healing (Figure 2).

\section{MSC-induced wound healing and angiogenesis}

Tissue repair and wound healing by MSC also involves angiogenesis and neo-vascularisation which requires interaction with endothelial cells. These interactions predominantly result in activation of the $\mathrm{WNT} / \beta$-catenin and Hedgehog signaling pathways while different factors and mechanisms depend on the type of MSC tissue origin which furthermore adds to the heterogenic functionality of MSC e.g., MSC migrate to damaged tissue lesions during skin repair and replace lost cells by transdifferentiation into various skin cell types [62]. The successful maintenance of such repair mechanisms also necessitates angiogenesis and neo-vascularisation of the restored tissue. Thus, other work has demonstrated that adipose tissue-derived MSC activation of endothelial cells and subsequent vessel morphogenesis is mediated preferably via the serine proteases of the plasmin family including urokinase-type plasminogen activator in conjunction with hepatocytes growth factor and tumor necrosis factor- $\alpha$ (TNF- $\alpha$ ) which contribute to vessel enlargement [63]. Whereas this activation system for vessel invasion and elongation within the fibrin-enriched extracellular matrix resembles that of fibroblasts, a different set of serine proteases such as matrix metalloproteinases are used by BM-MSC to promote angiogenesis via local endothelial cells [64]. However, chronic tissue damage such as chronic gastritis following Helicobacter pylori infection or chronic liver injuries represent organ-associated tissue defects, whereby aberrant changes in the microenvironment involving biological materials and debris from necrotic/apoptotic cells can derail MSC-mediated repair processes and may result in the promotion of neoplasias $[48,49,65]$ (Figure 1, Figure 2).

In sum, the population diversity of the MSC primary cultures and the various tissue origins of the MSC populations determine their plasticity in combination with cellular interactions, released cytokines and chemokines and the multiple effects of miRs. Such a functional diversity also applies to the divergent role of MSC on interacting cell types such as immune cells.

\section{Interaction of MSC with immune cells for immune- modulatory and immune-privileged functions}

Some important properties of hMSC are reflected by their functional interaction with a variety of immunecompetent cells [66]. In particular, tissue-originating hMSC populations such as bone marrow-, adipose tissue- or umbilical cord-derived hMSC selectively alter immune cell functions by suppressing e.g. T cell activation or dendritic cells or by inhibiting the cytotoxic capacity of natural killer (NK) cells. Thus, part of the immune-suppressive capacity is attributed to a direct cell-to-cell contact between hMSC and immune cells probably through the interaction of membrane receptors, adhesion molecules or the cellular exchange of membrane vesicles. Indeed, previous work has demonstrated that activated NK cells produce and release $\gamma$ IFN which induces up-regulation of HLA class I on MSC [67]. In return, HLA molecules expressed on MSC including HLA-G increasingly bind to the inhibitory receptor ILT2 (CD85j) expressed on NK cells [68] and subsequently contribute to the suppression of NK cell functions by a down-modulation of activating NK cell receptors NKp30 (CD337), NKp44 (CD336), and NKG2D (CD314) and by inhibition of NK-cell lytic granule formation [69] (Figure 1, Figure 2).

Moreover, MSC express glycoproteins such as galectin-1 in intracellular compartments as well as on their cell surface which selectively inhibits $\mathrm{T}$ cell activation. Thus, galectin-1 knockdown in MSC partially restores the proliferation of $\mathrm{CD}_{4}^{+}$and $\mathrm{CD}^{+} \mathrm{T}$ cells without any detectable effects on NK cells [70]. Furthermore, cytokine-inducible levels of different adhesion molecules including VCAM-1 and ICAM-1 are also detectable on MSC which are required for a direct adhesion of MSC to T lymphocytes and subsequent MSCmediated immunosuppression [71]. Whereas ICAM-1 and VCAM-1 are upregulated in MSC by pro-inflammatory cytokines such as TNF $\alpha$ and IL-1 $\beta$ in combination with $\gamma$-IFN, these effects enable MSC to increase adhesion to $\mathrm{T}$ cells. Moreover, this cell adhesion-mediated immunosuppression by MSC-to-lymphocyte attachment can be significantly reversed in vitro and in vivo after inhibition of adhesion via specific blocking antibodies or via adhesion molecule gene knockout [71]. These effects underscore the necessity of a direct MSC-tocell interaction to convey immune suppression (Figure 1, Figure 2).

In addition to the MSC's adhesive capacity by interactive adhesion molecules, further immunosuppressive mechanisms are relayed in part by a variety of different cytokines and other soluble factors which are produced 
and released by hMSC. These include cytokine receptor ligands (CXCL1, CXCL2, CXCL6), interleukins (IL-1, IL6, IL-8, IL-10, IL-11, IL-12, IL-14, IL-15), hematopoiesisstimulating factors (SCF, HGF, G-CSF, M-CSF, GMCSF), angiogenic growth factors (VEGF, VEGF-D, PlGF), and tropic growth factors (bFGF, FGF-4, EGF, HB-EGF, IGF-I, IGF-II, different forms of PDGF, TGF- $\beta$, TGF- $\beta 2$, TGF- $\beta 3$ ) [72-82]. Moreover, expression of nitric oxide synthase by MSC which can be enhanced by TNF $\alpha$ and $\gamma$-IFN, is associated with increased production of nitric oxide by MSC and inhibits T cell proliferation [83]. Furthermore, cyclooxygenase as well as indoleamine 2,3dioxygenase (IDO) which are inducible by $\gamma$-IFN, represent synergistically acting key molecules involved in $\mathrm{T}$ cell immune suppression. Cyclooxygenase metabolizes polyunsaturated fatty acids like arachidonic acid into prostaglandins such as $\mathrm{PGE}_{2}[84,85]$ which is involved at least in part in the inhibition of cytokine release by $\mathrm{T}$ cells [83]. The molecular mechanism of IDO is suggested to act through the catalyzed conversion of tryptophan to kynurenine, whereby the tryptophan depletion as well as the availability of kynurenine and further metabolites within the hMSC microenvironment contribute to suppress $\mathrm{T}$ cell proliferation $[86,87]$ (Figure 1, Figure 2).

Besides the various immune-modulatory effects of MSC depending on the activation status and the microenvironmental stimulation, there are also controversial data regarding the interaction between MSC and B cells. Studies in a mouse system have documented, that coculture of BM-MSC with B cells reduced the proliferative capacity and the immunoglobulin (Ig) production of the previously LPS-stimulated immune cells [88]. Moreover, B-cell proliferation was also inhibited and IgM, IgG, and IgA production significantly reduced by BMhMSC [89]. In contrast, other work has demonstrated an increased proliferation and IgG production of B cells after co-culturing with BM-MSC [90]. Likewise, purified $\mathrm{B}$ cells which required cell-to-cell contact with MSC for their activation, exhibited increased polyclonal proliferation and differentiation of naïve and transitional B cells into Ig-producing cells [91].

Although precise molecular interactions still remain unclear, how the two different actions of MSC mediate immune-modulation, either by direct MSC-to-immune cell attachment (e.g. via ICAM-1 and VCAM-1) or by the release of a large panel of cytokines and micro vesicle-containing miRs, it becomes more and more conceivable that both mechanisms may be mutually combined rather than representing exclusive phenomena. Based on this hypothesis, the direct and timely limited MSC-to-immune cell attachment could trigger and enhance a short-term release of required factors which contribute to immune cell-specific (either macrophages,
T-, B-, NK- or dendritic cells) responses. In addition, the MSC-immune cell attachment establishes a close interpopulation complex which provides a minimized intercellular space for maximal action of the released cytokines and micro vesicles within this microenvironment (Figure 2).

\section{Clinical use of MSC immune-privileged properties}

Besides their immune-modulatory capacity, hMSC also possess immune-privileged properties which means that these cells do not challenge a response of allogeneic immune cells suggesting an active self-protection [92]. Due to low expression levels of MHCI and MHCII antigens, hMSC represent valuable prerequisites for the medicinal use during cell or tissue transplantation. Therefore, the significantly reduced immunogenicity favors a low rejection rate of transplantable hMSC providing a preferred tool in regenerative medicine. However, the hMSC state of immune privilege remains unstable in the course of higher $\gamma$-IFN concentrations or differentiation-inducing effects within the hMSC microenvironment which elevate $\mathrm{MHCI}$ and particularly MHCII expression and cause a transition from an immune-privileged to an immunogenic phenotype associated with the induction of cellular cytotoxicity or immune rejection $[69,93]$.

Taken together, hMSC represent a heterogeneous population of stromal/stem cells originating from perivascular niches of nearly all tissues which exhibit altered proliferation and differentiation capacities, and provide distinct levels of immune-modulatory activities [92]. This immune-suppressive potential of MSC may not only allow their use for autologous, but also for allogeneic cell therapies in regenerative medicine. Moreover, MSC also display various roles in stem cell homing and tissue repair connected with cell differentiation, cell replacement, and neo-vascularisation. Although a variety of MSC functions still remain controversial and poorly understood, this stem cell population provides a very promising cellular tool in the field of regenerative medicine. The advantage of distinct hMSC, particularly the ethically non-controversial populations derived from neonatal tissues and their clinical potential are useful prerequisites for transplantation in view of cell and/ or tissue replacement in combination with their functional biodiversity [94]. Accordingly, MSC have been successfully applied in a variety of clinical trials, e.g. large bone defects [95] and cartilage lesions [96], spinal cord injuries [97], cardiovascular diseases [98], hematological pathologies [99], osteogenesis imperfecta [100], and graft-versus host disease [101]. However, MSC also display a large panel of interactions with diseased cells including a variety of tumor cells which may not always be beneficial for maintaining a healthy microenvironment. 


\section{Interaction of MSC with tumor cells and a tumorigenic microenvironment}

According to the heterogeneity of MSC functions already observed during MSC interaction with normal cells and particularly immune cells, there are also a variety of controversial reports suggesting both, tumorinhibitory and tumor-promoting activities of MSC. These conflicting observations may be related in part to the cellular microenvironment whereby hypoxia establishes an extracellular milieu to reduce aging and enrich poorly differentiated tumor cells and mesenchymal stro$\mathrm{mal} / \mathrm{stem}$ cells. Such an undifferentiated hypoxic microenvironment provides essential cellular interactions and environmental signals for the preferential maintenance of MSC and cancer cells $[24,48,49,102]$.

The contradictory reports on cellular interactions between MSC and tumors can also be associated with different activation levels of MSC which are switched by intracellular triggers such as different miRs. Indeed, different states of MSC activation are relayed by variable expression levels of certain miR including miR-335. High levels of miR-335 expression contribute to a potentially non-activated (silenced) MSC state of auto-maintenance and low amounts of miR-335 suggest an activated state leading to proliferation, migration and differentiation in MSC [103] (Figure 1).

\section{Tumor-promoting effects of MSC by exosomes and MSC- to-tumor cell contacts}

Of interest, a functional role in the regulation of a neoplastic development and the formation of metastases has also been attributed to miRs in breast cancer cells, particularly miR-21 and miR-205 for tumor development and miR-126 and miR-335 for breast cancer metastases. Whereas different amounts of miR-335 determine the activation status of MSC, certain expression levels of this miR also contribute to metastasis of breast cancer cells. The constitutive expression of miR-335 targets more than 62 genes [103] including the transcription factor SOX4 and the extracellular matrix component tenascin C. Thus, a down-modulation of this miR and consequently, increased expression of target genes is associated with enhanced risk of mammary tumor spreading and formation of metastasis. Likewise, miR-126 downmodulation is accompanied by an overall tumor growth and proliferation [104]. Therefore, constitutive intracellular amounts of these miRs are considered to exhibit metastasis-inhibitory capabilities and consequently, tumorinhibitory function may be related to relevant expression levels of additional miRs.

Tumor-promoting effects are also attributed to an epithelial-to-mesenchymal transition (EMT), whereby MSC play a crucial role. Thus, EMT represents a key event for colorectal cancer progression and MSC are implicated in this process [105]. Likewise, EMT is involved in metastatic breast cancer. During conversion of epithelial breast cancer cells to a mesenchymal phenotype and loss of apical-basolateral polarity, the tumor cells acquire morphological features and stem cell-like characteristics as compared to MSC [106] and may therefore resemble breast cancer stem cells. In addition, MSC-released exosomes can induce vascular endothelial growth factor (VEGF) expression in tumor cells by activating extracellular signal-regulated kinase1/ 2 (ERK1/2) pathway [107] which contributes to enhanced angiogenesis and tumor growth.

Interactions of MSC with breast cancer cells include the formation of gap junctions [108] The gap junction represents a membrane spanning channel (connexon) on each of the junctional cell types formed by a hexamer of connexins and allows gap junctional intercellular communication (GIIC) by transcellular exchange of low molecular weight compounds including calcium ions $\left(\mathrm{Ca}^{2+}\right)$, inositol phosphates (different $\mathrm{IP}_{3}$ and $\mathrm{IP}_{4}$ ) and cyclic nucleotides Thus, a derailed GJIC or defects in GJIC can modulate the metastatic potential of the breast cancer cells [109]. Moreover, loss of GIIC correlates with malignant phenotype progression in neoplastic mammary tissue [110].

Consequently, MSC provide direct cell-cell contact with tumor cells whereby these interactions rather than soluble factors predominantly promote tumor cell proliferation and survival in vitro [111]. Indeed, cellular interactions between MSC and tumor cells are facilitated via ICAM-1 and VCAM-1 receptors which also play a role in normal tissues during MSC and T cell interactions. Correlating to the presence of ICAM-1 on the MSC, breast cancer cells express cell surface-associated mucin 1 (MUC1). MUC1 motifs can interact with ICAM-1 molecules and such ICAM-1-MUC1 interactions initiate an actin-based cell invasive motility [112]. MUC1 (CD227, DF3, CA15-3) represents a transmembrane heterodimeric glycoprotein normally expressed at the apical surface of mammary epithelium [113]. However, during breast cancer progression, cell polarization is frequently lost and consequently, MUC1 circumferentially distributes around the entire plasma membrane of the breast cancer cell or is highly overexpressed throughout the cytosol [114] (Figure 2).

At the molecular level, ICAM-1-MUC1 interactions activate Src kinase and subsequent Src-mediated phosphorylation of the cytoplasmic domain of MUC1 at two highly conserved Y-x-x-P sequences (Y35VPP38 and Y60TNP63) attribute to a direct recruitment of CrkL binding via its $\mathrm{SH} 2$ domain. The $\mathrm{SH} 2 / \mathrm{SH} 3$ adaptor protein CrkL is involved in the regulation of cell migration through the association with guanine nucleotide exchange factors such as Dock180 to catalyze GTPase 
activation and GDP/GTP exchange. Consequently, the ICAM-1-MUC1-mediated Src-CrkL complex formation further activates the small GTPases Rac1 and Cdc42 which are key effectors of the actin cytoskeleton protrusion machinery and thereby, reorganize the actin cytoskeleton and promote an actin-based cell motility [112]. Supportive studies have demonstrated, that MSC contribute to alter stiffness via small GTPases Rho A and Cdc42 [115]. Finally, the enhanced motility of the MUC1-carrying tumor cells contributes to a significantly elevated metastatic potential.

\section{Tumor-inhibitory effects of MSC by ECM and soluble factors}

Together, these studies suggest that direct cell-to-cell interactions between MSC and tumor cells via gap junctions and the exchange of exosomes or via membrane receptor assembly promote tumor cell growth. In contrast, tumor inhibitory effects of MSC are reported preferentially via the ECM compounds of the microenvironment and soluble factors (Figure 2). Thus, extracts from Wharton's jelly-derived MSC - either cell lysates or cell supernatants - inhibit cell growth of a variety of cancer cell lines including breast cancer, ovarian carcinoma, and osteosarcoma cells [116]. Moreover, $\beta$-IFN secreted by MSC within the tumor microenvironment and intratumorally produced $\beta$-IFN significantly reduces breast cancer growth and metastatic potential by inactivation of the constitutive phosphorylation of signal transducer activator transcription factor 3 (Stat3) via Src, and Akt kinases and a concomitant down-regulation of c-Myc and MMP2 expression [117]. Finally, ECM components produced by MSC contribute to arrest the growth of metastatic tumor cells by an up-regulation of the tumor suppressor phosphatase and tensin homolog (PTEN) in the tumor cells [98]. In addition, dickkopf (DKK1)-producing MSC are capable of inhibiting cancer cell proliferation independent of the tumor-inhibitory effect of MSC-generated ECM compounds [118].

More detailed studies in a tumor model revealed that UC-MSC possess a significantly elevated migratory potential as compared to BM-MSC. The capacity to migrate towards glioma cells is accompanied by an elevated expression of IL-8 receptors and CXC chemokine receptors- 1 and -2 on UC-MSC [119]. Malignant glioma cells have been demonstrated to recruit MSC by secreting angiogenic factors, such as VEGF [120], and cytokines, including IL-8 [121]. In addition, MMPs and the corresponding MMP tissue inhibitors are associated with MSC migration to injured tissues [122]. In vivo application of MSC into the contralateral hemisphere of a glioma in rats was associated with migration of the MSC towards the tumor through the corpus callosum. Moreover, intratumoral injection of MSC resulted in a significant inhibition of tumor growth and increased the survival of these rats [123]. In the human system, MSC integrate into gliomas after intravascular or local injection [124]. Since MSC are capable of homing to gliomas (likewise to other tumor entities), these multipotent stem cells have been suggested a powerful cellular vehicle to target tumor cells [125]. In addition, the capability of MSC to release exosomes, represents a potentially useful tool for a specific delivery of customized anti-cancer compounds $[126,127]$.

In conclusion, these effects suggest that MSC display tumor-inhibitory functions preferably via the ECM and the release of distinct factors into the tumor surrounding microenvironment, whereas tumor-promoting effects are relayed predominantly by direct cell-to-cell interaction and the exchange of membrane vesicles.

\section{Aberrant MSC}

A variety of further evidences suggest that disease- and cancer-associated stromal cells are distinctly abnormal as compared to MSC from healthy tissues. E.g., multiple myeloma represents a plasma cell malignancy characterized by complex heterogeneous cytogenetic abnormalities and a significant amount of MSC derived from multiple myeloma carry chromosomal abnormalities and defects in gene and protein expression [128]. Likewise, MSC cultured from patients with severe systemic sclerosis constitutively release higher levels of cytokines/chemokines such as SDF-1 and VEGF and stimulate microvascular endothelial cell angiogenesis much more efficiently as compared to normal BM-MSC [129]. The development of certain sarcomas as mesenchymal tumors has also been attributed to originate from aberrant MSC, whereby the WNT signaling pathway plays an important role to exert tumor suppression and conversely, its inhibition is accompanied by sarcoma genesis [130]. Moreover, growth of BM-hMSC in long-term cultures (5-106 weeks) was associated with a spontaneous malignant transformation which occurred in about half of these cultures and demonstrated a significantly increased proliferation rate and an altered morphology and phenotype [131]. The close vicinity of MSC to neighboring cells via adhesion receptors and/or the exchange of exosomes can also favor cell fusion and the formation of multinucleated cells which alters MSC functionality (Figure 1, Figure 2). Previous observations with BM-hMSC in certain neurodegenerative disorders and flow cytometry of fluorescentlylabeled MSC in co-culture with nucleus pulposus cells revealed evidence for the formation of gap junctions and some cell fusion although these phenomena 
occur at low frequency [132,133]. Similar observations are confirmed during co-culture of UC-hMSC with the human breast cancer cell line MDA-MB-231 (Figure 3).

The close vicinity of MSC to the tumor entity also enables interactions with biological material obtained from necrotic tumor tissue and dying cancer cells. Such necrotic factors - also termed damage-associated molecular patterns (DAMPs), can activate MSC by enhancing their angiogenic capacity or affect the immuneregulatory potential of MSC by interfering with the expression of indoleamine 2,3-dioxygenase in MSC [134]. Moreover, whole necrotic vesicles or apoptotic bodies from dead tumor cells can be incorporated into MSC by engulfment or fusion contributing to transform the MSC functionality. Thus, BM-hMSC which have been cultured in tumor-conditioned medium for up to $30 \mathrm{~d}$ acquire functional properties of carcinoma-associated fibroblasts (CAF). These CAF-like transformed MSC express myofibroblast markers, including $\alpha$-smooth muscle actin and fibroblast surface protein and produce sustained levels of SDF-1 (Figure 1, Figure 2). Simultaneously, these CAF-like MSC also promote tumor cell growth both, in vitro and in an in vivo coimplantation model [135]. Likewise, MSC transformed with specific mutations play an important role in sarcoma genesis and in the control of sarcoma tumor growth [136,137]. Furthermore, MSC which have been isolated from primary breast cancer tissues significantly

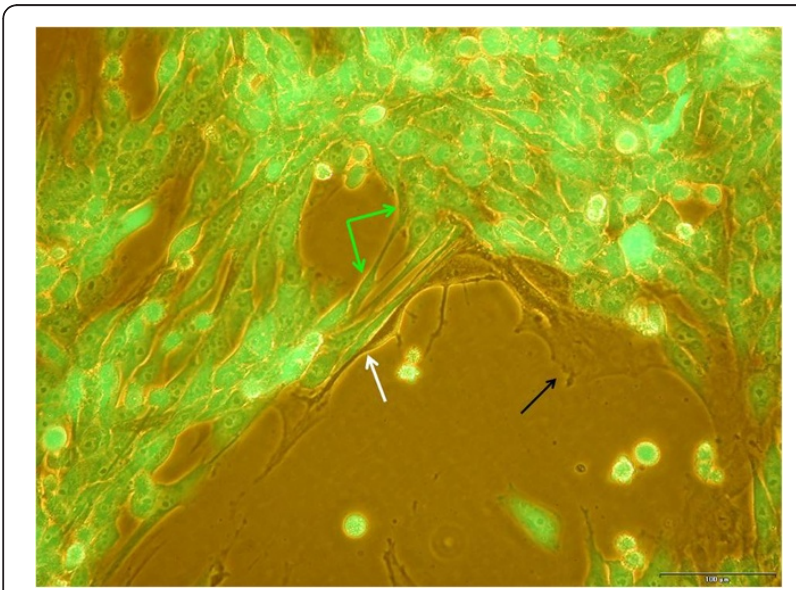

Figure 3 Phase contrast/fluorescence microscopy overlay of primary umbilical cord-derived hMSC (black arrow) and lentivirus vector GFP- transfected MDA-MB-231 human breast carcinoma cells (green cells) originally seeded in a ratio of 60:40 (MSC: MDA-MB-231) and co-cultured for 7d. A certain amount of spindle-shaped MSC surrounded the tumor cells (white arrow). However, as judged by the morphology, a small amount of these spindle-shaped cells appeared with green fluorescence (green arrows) which may indicate a possible fusion of MSC with GFPcontaining exosomes or a complete MSC-breast cancer cell fusion with 2 nuclei (green arrows). Bar graph demonstrates $100 \mu \mathrm{m}$. promote tumor growth and size following $\mathrm{CO}^{-}$ transplantation with breast cancer cells. These tumorderived MSC release EGF and promote mammosphere formation via the PI3K/Akt signaling pathway [138]. Finally, MSC display some similarities to aged normal mammary epithelial cells and tumorigenic human breast epithelial cells particularly after EMT with respect to the gene expression pattern [139] and some surface receptor levels $[140,141]$. This functional association underscores the involvement of stem cells associated with breast cancer and their supportive role according to stimulatory effects from the microenvironment [142, 143].

Together, MSC can directly interact with a variety of different adjacent normal cell types either via adhesion molecules and gap junctions or via exchange of a large panel of cytokines/chemokines, exosomecontaining miRs and ECM components. In case of tumor cells, such interactions with MSC result in the support of tumor-promoting and tumor-inhibiting activities, respectively. Moreover, uptake of DAMPs and fusion with vesicles or apoptotic bodies from tumor cells contribute to alter the MSC functionality into an aberrant phenotype.

\section{Conclusions}

MSC demonstrate a functional heterogeneity within different tissue origins. This heterogeneity is even displayed within the same population and suggests MSC subpopulations exhibiting specialized functions according to local tissue requirements which may develop from certain precursor cells and still maintain stem cell properties [144]. Thereby, MSC can maturate predominantly along phenotypes of the mesoderm lineage, protect hematopoietic stem cells, modulate the reactivity of immune cells (e.g. macrophages, NK-, T-, B-, dendritic cells), activate endothelial cells and either suppress tumor growth via ECM and soluble factors (e.g. gliomas) or enhance the motility and metastatic capacity of tumor cells via exosome exchange and direct cell-to-cell contact (e.g. breast cancer cells). The heterogeneity of MSC is also reflected by molecular triggers such as cytokines or the intracellular expression levels of certain miRs that alter the MSC state of activation in order to self-renew, maintain stemness, regulate stem cell homeostasis, undergo differentiation, migrate towards tissue damage, modulate immune cell functions, support angiogenesis, and promote or inhibit cancer growth and metastasis.

Whereas MSC appear to function almost as a cellular all-rounder in support of tissue homeostasis and plasticity, these unique capabilities of biodiversity may also be misused during transformation into aberrant MSC phenotypes. 


\section{Competing interests}

The authors declare that they have no competing interests.

\section{Authors contribution}

$\mathrm{AO}$ contributed to Figure 1 and Figure 2. $\mathrm{RH}$. finalized the figures and drafted the manuscript. All authors read and approved the final manuscript.

\section{Acknowledgement}

This work was supported by a grant from the Niedersächsische Krebsgesellschaft to R.H.. Moreover, this work was supported for Open Access Publication by the German Research Foundation (DFG).

Received: 25 July 2012 Accepted: 28 August 2012

Published: 3 September 2012

\section{References}

1. Friedenstein AJ, Gorskaja JF, Kulagina NN: Fibroblast precursors in normal and irradiated mouse hematopoietic organs. Exp Hematol 1976, 4:267-274.

2. Fraser JK, Wulur I, Alfonso Z, Hedrick MH: Fat tissue: an underappreciated source of stem cells for biotechnology. Trends Biotechnol 2006, 24:150-154

3. Cao C, Dong Y: Study on culture and in vitro osteogenesis of bloodderived human mesenchymal stem cells. Zhongguo Xiu Fu Chong Jian Wai Ke Za Zhi 2005, 19:642-647.

4. Beltrami AP, Barlucchi L, Torella D, Baker M, Limana F, Chimenti S, Kasahara H, Rota M, Musso E, Urbanek K, Leri A, Kajstura J, Nadal-Ginard B, Anversa P: Adult cardiac stem cells are multipotent and support myocardial regeneration. Cell 2003, 114:763-776.

5. Griffiths MJ, Bonnet D, Janes SM: Stem cells of the alveolar epithelium. Lancet 2005, 366:249-260.

6. De Coppi P, Bartsch G Jr, Siddiqui MM, Xu T, Santos CC, Perin L, Mostoslavsky G, Serre AC, Snyder EY, Yoo JJ, Furth ME, Soker S, Atala A Isolation of amniotic stem cell lines with potential for therapy. Nat Biotechnol 2007, 25:100-106.

7. Miki T, Lehmann T, Cai H, Stolz DB, Strom SC: Stem cell characteristics of amniotic epithelial cells. Stem Cells 2005, 23:1549-1559.

8. Tamagawa T, Oi S, Ishiwata I, Ishikawa H, Nakamura Y: Differentiation of mesenchymal cells derived from human amniotic membranes into hepatocyte-like cells in vitro. Hum Cell 2007, 20:77-84.

9. Wolbank S, van Griensven M, Grillari-Voglauer R, Peterbauer-Scherb A: Alternative sources of adult stem cells: human amniotic membrane. Adv Biochem Eng Biotechnol 2010, 123:1-27.

10. Soncini M, Vertua E, Gibelli L, Zorzi F, Denegri M, Albertini A, Wengler GS, Parolini O: Isolation and characterization of mesenchymal cells from human fetal membranes. J Tissue Eng Regen Med 2007, 1:296-305.

11. Igura K, Zhang X, Takahashi K, Mitsuru A, Yamaguchi S, Takashi TA: Isolation and characterization of mesenchymal progenitor cells from chorionic villi of human placenta. Cytotherapy 2004, 6:543-553.

12. Anker PS I't, Scherjon SA, van der Keur Kleijburg C, de Groot-Swings GM, Claas FH, Fibbe WE, Kanhai HH: Isolation of mesenchymal stem cells of fetal or maternal origin from human placenta. Stem Cells 2004, 22:1338-1345.

13. Brooke $\mathrm{G}$, Tong $\mathrm{H}$, Levesque JP, Atkinso K: Molecular trafficking mechanisms of multipotent mesenchymal stem cells derived from human bone marrow and placenta. Stem Cells Dev 2008, 17:929-940.

14. Broxmeyer HE, Srour E, Orschell C, Ingram DA, Cooper S, Plett PA, Mead LE, Yoder MC: Cord blood stem and progenitor cells. Methods Enzymol 2006, 419:439-473.

15. Wang HS, Hung SC, Peng ST, Huang CC, Wei HM, Guo YJ, Fu YS, Lai MC, Chen CC: Mesenchymal stem cells in the Wharton's jelly of the human umbilical cord. Stem Cells 2004, 22:1330-1337.

16. Majore I, Moretti P, Stahl F, Hass R, Kasper C: Growth and differentiation properties of mesenchymal stromal cell populations derived from whole human umbilical cord. Stem Cell Rev Rep 2011, 7:17-31.

17. Baksh D, Yao R, Tuan RS: Comparison of proliferative and multilineage differentiation potential of human mesenchymal stem cells derived from umbilical cord and bone marrow. Stem Cells 2007, 25:1384-1392.

18. Wu LF, Wang NN, Liu YS, Wei X: Differentiation of Wharton's jelly primitive stromal cells into insulin-producing cells in comparison with bone marrow mesenchymal stem cells. Tissue Eng Part A 2009, 15:2865-2873.

19. Chen MY, Lie PC, Li ZL, Wei X: Endothelial differentiation of Wharton's jelly-derived mesenchymal stem cells in comparison with bone marrowderived mesenchymal stem cells. Exp Hematol 2009, 37:629-640.
20. Lu LL, Liu YJ, Yang SG, Zhao QJ, Wang X, Gong W, Han ZB, Xu ZS, Lu YX, Liu D, Chen ZZ, Han ZC: Isolation and characterization of human umbilical cord mesenchymal stem cells with hematopoiesis-supportive function and other potentials. Haematologica 2006, 91:1017-1026.

21. Kern S, Eichler H, Stoeve J, Kluter H, Bieback K: Comparative analysis of mesenchymal stem cells from bone marrow, umbilical cord blood, or adipose tissue. Stem Cells 2006, 24:1294-1301.

22. Peng L, Jia Z, Yin X, Zhang X, Liu Y, Chen P, Ma K, Zhou C: Comparative analysis of mesenchymal stem cells from bone marrow, cartilage, and adipose tissue. Stem Cells Dev 2008, 17:761-773.

23. Bertram C, Hass R: Cellular responses to reactive oxygen species-induced DNA damage and aging. Biol Chem 2008, 389:211-220.

24. Lavrentieva A, Majore I, Kasper C, Hass R: Effects of hypoxic culture conditions on umbilical cord-derived human mesenchymal stem cells. Cell Commun Signal 2010, 8:18.

25. Hong L, Colpan A, Peptan IA, Daw J, George A, Evans CA: 17-Beta estradiol enhances osteogenic and adipogenic differentiation of human adiposederived stromal cells. Tissue Eng 2007, 13:1197-1203.

26. Hou T, Xu J, Wu X, Xie Z, Luo F, Zhang Z, Zeng L: Umbilical Cord Wharton's Jelly: A New Potential Cell Source of Mesenchymal Stroma Cells for Bone Tissue Engineering. Tissue Eng Part A 2009, 15:2325-34.

27. Awad HA, Halvorsen YD, Gimble JM, Guilak F: Effects of transforming growth factor beta1 and dexamethasone on the growth and chondrogenic differentiation of adipose-derived stromal cells. Tissue Eng 2003, 9:1301-1312.

28. Hass R: Retrodifferentiation-a mechanism for cellular regeneration? Biol Chem 2009, 390:409-416.

29. Hass R: Rejuvenation in distinct cell populations - What does it mean? Exp Gerontol 2009, 44:634-638.

30. Macias Ml, Grande J, Moreno A, Domínguez I, Bornstein R, Flores Al: Isolation and characterization of true mesenchymal stem cells derived from human term decidua capable of multilineage differentiation into all 3 embryonic layers. Am J Obstet Gynecol 2010, 203:495. e9-495.e23.

31. Phinney DG, Prockop DJ: Concise review: mesenchymal stem/multipotent stromal cells: the state of transdifferentiation and modes of tissue repair - current views. Stem Cells 2007, 25:2896-2902.

32. Majore I, Moretti P, Hass R, Kasper C: Identification of subpopulations in mesenchymal stem cell-like cultures from human umbilical cord. Cell Commun Signal 2009, 7:6.

33. Yegorov YE, Akimov SS, Hass R, Zelenin AV, Prudovsky IA: Endogenous beta-galactosidase activity in continuously nonproliferating cells. Exp Cell Res 1998, 243:207-211.

34. Dominici M, Le Blanc K, Mueller I, Slaper-Cortenbach I, Marini F, Krause D Deans R, Keating A, Prockop D, Horwitz E: Minimal criteria for defining multipotent mesenchymal stromal cells. The International Society for Cellular Therapy position statement. Cytotherapy 2006, 8:315-317.

35. Qian H, Le Blanc K, Sigvardsson M: Primary Mesenchymal Stem and Progenitor Cells from Bone Marrow Lack Expression of CD44 Protein. J Biol Chem 2012, 287:25795-807

36. Yu Q, Stamenkovic I: Localization of matrix metalloproteinase 9 to the cell surface provides a mechanism for CD44-mediated tumor invasion. Genes Dev 1999, 13:35-48.

37. Bertram C, Hass R: MMP-7 is involved in aging of primary human mammary epithelial cells (HMEC). Exp Gerontol 2008, 43:209-217.

38. Bertram C, Hass R: Cellular senescence of human mammary epithelial cells (HMEC) is associated with an altered MMP-7/HB-EGF signaling and increased formation of elastin-like structures. Mech Aging Dev 2009, 30:657-669.

39. Chaturvedi $S$, Hass R: Extracellular signals in young and aging breast epithelial cells and possible connections to age-associated breast cancer development. Mech Aging Dev 2011, 132:213-219.

40. Bucan V, Mandel K, Bertram C, Lazaridis A, Reimers K, Park-Simon TW, Vogt PM, Hass R: LEF-1 regulates proliferation and MMP-7 transcription in breast cancer cells. Genes to Cells 2012, 17:559-567.

41. Simmons PJ, Torok-Storb B: Identification of stromal cell precursors in human bone marrow by a novel monoclonal antibody, STRO-1. Blood 1991, 78:55-62.

42. Nasef A, Zhang YZ, Mazurier C, Bouchet S, Bensidhoum M, Francois S, Gorin NC, Lopez M, Thierry D, Fouillard L, Chapel A: Selected Stro-1-enriched bone marrow stromal cells display a major suppressive effect on lymphocyte proliferation. Int J Lab Hematol 2009, 31:9-19. 
43. Lin G, Liu G, Banie L, Wang G, Ning H, Lue TF, Lin CS: Tissue distribution of mesenchymal stem cell marker Stro-1. Stem Cells Dev 2011, 20:1747-1752.

44. Honczarenko M, Le Y, Swierkowski M, Ghiran I, Glodek AM, Silberstein LE: Human bone marrow stromal cells express a distinct set of biologically functional chemokine receptors. Stem Cells 2006, 24:1030-1041.

45. Méndez-Ferrer S, Michurina TV, Ferraro F, Mazloom AR, Macarthur BD, Lira SA, Scadden DT, Ma'ayan A, Enikolopov GN, Frenette PS: Mesenchymal and haematopoietic stem cells form a unique bone marrow niche. Nature 2010, 466:829-834

46. Wislet-Gendebien $\mathrm{S}$, Laudet $\mathrm{E}$, Neirinckx V, Alix P, Leprince $\mathrm{P}$, Glejzer A, Poulet C, Hennuy B, Sommer L, Shakhova O, Rogister B: Mesenchymal stem cells and neural crest stem cells from adult bone marrow: characterization of their surprising similarities and differences. Cell Mol Life Sci 2012, 69:2593-2608.

47. Ungefroren $H$, Sebens S, Seidl D, Lehnert H, Hass R: Interaction of tumor cells with the microenvironment. Cell Commun Signal 2011, 9:18.

48. Friedl P, Alexander S: Cancer invasion and the microenvironment: plasticity and reciprocity. Cell 2011, 147:992-1009.

49. Alexander S, Friedl P: Cancer invasion and resistance: interconnected processes of disease progression and therapy failure. Trends Mol Med 2012, 18:13-26.

50. Chen TS, Lai RC, Lee MM, Choo AB, Lee CN, Lim SK: Mesenchymal stem cell secretes microparticles enriched in pre-microRNAs. Nucleic Acids Res 2010, 38:215-224.

51. Collino F, Bruno S, Deregibus MC, Tetta C, Camussi G: MicroRNAs and mesenchymal stem cells. Vitam Horm 2011, 87:291-320.

52. Guo L, Zhao RC, Wu Y: The role of microRNAs in self-renewal and differentiation of mesenchymal stem cells. Exp Hematol 2011, 39:608-616.

53. Bork S, Horn P, Castoldi M, Hellwig I, Ho AD, Wagner W: Adipogenic differentiation of human mesenchymal stromal cells is down-regulated by microRNA-369-5p and up-regulated by microRNA-371. J Cell Physiol 2011, 226:2226-2234.

54. Broxmeyer HE: Chemokines in hematopoiesis. Current opinion in hematology 2008, 15:49-58.

55. Pillai MM, Yang X, Balakrishnan I, Bemis L, Torok-Storb B: MiR-886-3p down regulates $\mathrm{CXCL12}$ (SDF1) expression in human marrow stromal cells. PLOS One 2010, 5(12):e14304.

56. Chen L, Tredget EE, Wu PY, Wu Y: Paracrine factors of mesenchymal stem cells recruit macrophages and endothelial lineage cells and enhance wound healing. PLOS ONE 2008, 3:e1886.

57. Le Blanc K, Mougiakakos D: Multipotent mesenchymal stromal cells and the innate immune system. Nat Rev Immunol 2012, 12:383-96.

58. Anton K, Banerjee D, Glod J: Macrophage-associated mesenchymal stem cells assume an activated, migratory, pro-inflammatory phenotype with increased IL-6 and CXCL10 secretion. PLoS One 2012, 7:e35036.

59. Spaggiari GM, Capobianco A, Abdelrazik H, Becchetti F, Mingari MC, Moretta L: Mesenchymal stem cells inhibit natural killer-cell proliferation, cytotoxicity, and cytokine production: role of indoleamine 2,3-dioxygenase and prostaglandin E2. Blood 2008, 111:1327-1333.

60. Mosser DM, Edwards JP: Exploring the full spectrum of macrophage activation. Nature Rev Immunol 2008, 8:958-969.

61. Maggini J, Mirkin G, Bognanni I, Holmberg J, Piazzón IM, Nepomnaschy I, Costa H, Cañones C, Raiden S, Vermeulen M, Geffner JR: Mouse bone marrow-derived mesenchymal stromal cells turn activated macrophages into a regulatory-like profile. PLOS ONE 2010, 5:e9252.

62. Sasaki M, Abe R, Fujita Y, Ando S, Inokuma D, Shimizu H: Mesenchymal stem cells are recruited into wounded skin and contribute to wound repair by transdifferentiation into multiple skin cell type. J Immuno/ 2008, 180:2581-2587.

63. Kachgal S, Putnam AJ: Mesenchymal stem cells from adipose and bone marrow promote angiogenesis via distinct cytokine and protease expression mechanisms. Angiogenesis 2011, 14:47-59.

64. Ghajar CM, Kachgal S, Kniazeva E, Mori H, Costes SV, George SC, Putnam AJ: Mesenchymal cells stimulate capillary morphogenesis via distinct proteolytic mechanisms. Exp Cell Res 2010, 316:813-825.

65. Arwert EN, Hoste E, Watt FM: Epithelial stem cells, wound healing and cancer. Nat Rev Cancer 2012, 12:170-180.

66. De Miguel MP, Fuentes-Julian S, Blazquez-Martinez A, Pascual CY, Aller MA, Arias J, Arnalich-Montiel F: Immunosuppressive properties of mesenchymal stem cells: advances and applications. Curr Mol Med 2012 12:574-591.
67. Spaggiari GM, Capobianco A, Becchetti S, Mingari MC, Moretta L: Mesenchymal stem cell-natural killer cell interactions: evidence that activated NK cells are capable of killing MSC, whereas MSC can inhibit IL-2-induced NK-cell proliferation. Blood 2006, 107:14841490.

68. Shiroishi M, Tsumoto K, Amano K, Shirakihara Y, Colonna M, Braud VM, Allan DS, Makadzange A, Rowland-Jones S, Willcox B, Jones EY, van der Merwe PA, Kumagai I, Maenaka K: Human inhibitory receptors Ig-like transcript 2 (ILT2) and ILT4 compete with CD8 for MHC class I binding and bind preferentially to HLA-G. Proceedings of the National Academy of Sciences of the United States of America 2003, 100:8856-8861.

69. Favier B, Lemaoult J, Lesport E, Carosella ED: ILT2/HLA-G interaction impairs NK-cell functions through the inhibition of the late but not the early events of the NK-cell activating synapse. The FASEB journal: official publication of the Federation of American Societies for Experimental Biology 2010, 24:689-699.

70. Gieseke F, Böhringer J, Bussolari R, Dominici M, Handgretinger R, Müller I: Human multipotent mesenchymal stromal cells use galectin-1 to inhibit immune effector cells. Blood 2010, 116:3770-3779.

71. Ren G, Zhao X, Zhang L, Zhang J, L'Huillier A, Ling W, Roberts Al, Le AD, Shi S, Shao C, Shi Y: Inflammatory cytokine-induced intercellular adhesion molecule-1 and vascular cell adhesion molecule-1 in mesenchymal stem cells are critical for immunosuppression. J Immunol 2010, 184:2321-2328.

72. Montesinos JJ, Flores-Figueroa E, Castillo-Medina S, Flores-Guzman P, Hernandez-Estevez E, Fajardo-Orduna G, Orozco S, Mayani H: Human mesenchymal stromal cells from adult and neonatal sources: comparative analysis of their morphology, immunophenotype, differentiation patterns and neural protein expression. Cytotherapy 2009 11:163-176.

73. Zeddou M, Briquet A, Relic B, Josse C, Malaise MG, Gothot A, Lechanteur C, Beguin $Y$ : The umbilical cord matrix is a better source of mesenchymal stem cells (MSC) than the umbilical cord blood. Cell biology international 2010, 34:693-701.

74. Hatlapatka T, Moretti P, Lavrentieva A, Hass R, Marquardt N, Jacobs R, Kasper C: Optimization of Culture Conditions for the Expansion of Umbilical Cord-Derived Mesenchymal Stem or Stromal Cell-Like Cells Using Xeno-Free Culture Conditions. Tissue Eng Part C Methods 2011, 4:485-493.

75. Moretti P, Hatlapatka T, Marten D, Lavrentieva A, Majore I, Hass R, Kasper C: Mesenchymal stromal cells derived from human umbilical cord tissues: primitive cells with potential for clinical and tissue engineering applications. Advances in Biochemical Engineering/Biotechnology 2010, 123:29-54.

76. Casiraghi F, Noris M, Remuzzi G: Immunomodulatory effects of mesenchymal stromal cells in solid organ transplantation. Current opinion in organ transplantation 2010, 15:731-737.

77. Haynesworth SE, Baber MA, Caplan Al: Cytokine expression by human marrow-derived mesenchymal progenitor cells in vitro: effects of dexamethasone and IL-1 alpha. Journal of cellular physiology 1996, 166:585-592.

78. Albini A, Melchiori A, Santi L, Liotta LA, Brown PD, Stetler-Stevenson WG: Tumor cell invasion inhibited by TIMP-2. Journal of the National Cancer Institute 1991, 83:775-779.

79. Di Nicola M, Carlo-Stella C, Magni M, Milanesi M, Longoni PD, Matteucci P, Grisanti S, Gianni AM: Human bone marrow stromal cells suppress Tlymphocyte proliferation induced by cellular or nonspecific mitogenic stimuli. Blood 2002, 99:3838-3843.

80. Patel SA, Meyer JR, Greco SJ, Corcoran KE, Bryan M, Rameshwar P. Mesenchymal stem cells protect breast cancer cells through regulatory $T$ cells: role of mesenchymal stem cell-derived TGF-beta. Journal of immunology (Baltimore, Md: 19 2010, 184:5885.

81. Lama VN, Smith L, Badri L, Flint A, Andrei AC, Murray S, Wang Z, Liao H, Toews GB, Krebsbach PH, et al: Evidence for tissue-resident mesenchymal stem cells in human adult lung from studies of transplanted allografts. The Journal of clinical investigation 2007, 117:989-996.

82. Ren G, Zhang L, Zhao X, Xu G, Zhang Y, Roberts Al, Zhao RC, Shi Y: Mesenchymal stem cell-mediated immunosuppression occurs via concerted action of chemokines and nitric oxide. Cell stem cell 2008, 2:141-150

83. Zinöcker $\mathrm{S}$, Vaage JT: Rat mesenchymal stromal cells inhibit $\mathrm{T}$ cell proliferation but not cytokine production through inducible nitric oxide synthase. Front Immunol 2012, 3:62. 
84. Koehler L, Hass R, DeWitt DL, Resch K, Goppelt-Struebe M: Glucocorticoidinduced reduction of prostanoid synthesis in TPA-differentiated U937 cells is mainly due to a reduced cyclooxygenase activity. Biochem Pharmacol 1990, 40:1307-1316.

85. Koehler L, Hass R, Goppelt-Struebe M, Kaever V, Resch K: Differential effect of dexamethasone on the regulation of phospholipase A2 and prostanoid synthesis in undifferentiated and phorbolester-differentiated U937 cells. J Cell Biochem 1989, 40:397-406.

86. Meisel R, Zibert A, Laryea M, Gobel U, Daubener W, Dilloo D: Human bone marrow stromal cells inhibit allogeneic T-cell responses by indoleamine 2,3-dioxygenase-mediated tryptophan degradation. Blood 2004, 103:4619-4621.

87. Frumento G, Rotondo R, Tonetti M, Damonte G, Benatti U, Ferrara GB: Tryptophan-derived catabolites are responsible for inhibition of $T$ and natural killer cell proliferation induced by indoleamine 2,3-dioxygenase. The Journal of experimental medicine 2002, 196:459-468

88. Deng W, Han Q, Liao L, You S, Deng H, Zhao RC: Effects of allogeneic bone marrow-derived mesenchymal stem cells on $T$ and $B$ lymphocytes from BXSB mice. DNA Cell Biol 2005, 24:458-463.

89. Corcione A, Benvenuto F, Ferretti E, Giunti D, Cappiello V, Cazzanti F, Risso M, Gualandi F, Mancardi GL, Pistoia V, Uccelli A: Human mesenchymal stem cells modulate B-cell functions. Blood 2006, 107:367-372.

90. Rasmusson I, Le Blanc K, Sundberg B, Ringden O: Mesenchymal stem cells stimulate antibody secretion in human B cells. Scand J Immunol 2007, 65:336-343.

91. Traggiai E, Volpi S, Schena F, Gattorno M, Ferlito F, Moretta L, Martini A: Bone marrow-derived mesenchymal stem cells induce both polyclonal expansion and differentiation of B cells isolated from healthy donors and systemic lupus erythematosus patients. Stem Cells 2008, 26:562-569.

92. Hass R, Kasper C, Böhm S, Jacobs R: Different populations and sources of human mesenchymal stem cells (MSC): A comparison of adult and neonatal tissue-derived MSC. Cell Commun Signal 2011, 9:12.

93. Huang XP, Sun Z, Miyagi Y, McDonald Kinkaid H, Zhang L, Weisel RD, Li RK Differentiation of allogeneic mesenchymal stem cells induces immunogenicity and limits their long-term benefits for myocardial repair. Circulation 2010, 122:2419-2429.

94. Hilfiker A, Kasper C, Hass R, Haverich A: Mesenchymal stem cells and progenitor cells in connective tissue engineering and regenerative medicine: Is there a future for transplantation? Langenbeck's Arch Surgery 2011, 396:489-497.

95. Kraus KH, Kirker-Head C: Mesenchymal stem cells and bone regeneration. Vet Surg 2006, 35:232-242.

96. Mobasheri A, Csaki C, Clutterbuck AL, Rahmanzadeh M, Shakibaei M: Mesenchymal stem cells in connective tissue engineering and regenerative medicine: applications in cartilage repair and osteoarthritis therapy. Histol Histopathol 2009, 24:347-366.

97. Sykova $E$, Jendelova $P$, Urdzikova L, Lesny $P$, Hejcl A: Bone marrow stem cells and polymer hydrogels-two strategies for spinal cord injury repair. Cell Mol Neurobiol 2006, 26:1113-1129.

98. Perin EC, Dohmann HF, Borojevic R, Silva SA, Sousa AL, Silva GV, Mesquita CT, Belem L, Vaughn WK, Rangel FO, Assad JA, Carvalho AC, Branco RV, Rossi MI, Dohmann HJ, Willerson JT: Improved exercise capacity and ischemia 6 and 12 months after transendocardial injection of autologous bone marrow mononuclear cells for ischemic cardiomyopathy. Circulation 2004, 110: ||213-|1218.

99. Lazarus HM, Koc ON, Devine SM, Curtin P, Maziarz RT, Holland HK, Shpall EJ, McCarthy P, Atkinson K, Cooper BW, Gerson SL, Laughlin MJ, Loberiza FR Jr, Moseley AB, Bacigalupo A: Cotransplantation of HLA-identical sibling culture-expanded mesenchymal stem cells and hematopoietic stem cells in hematologic malignancy patients. Biol Blood Marrow Transplant 2005, 11:389-398.

100. Horwitz EM, Prockop DJ, Gordon PL, Koo WW, Fitzpatrick LA, Neel MD, McCarville ME, Orchard PJ, Pyeritz RE, Brenner MK: Clinical responses to bone marrow transplantation in children with severe osteogenesis imperfecta. Blood 2001, 97:1227-1231.

101. Le Blanc K, Rasmusson I, Sundberg B, Gotherstrom C, Hassan M, Uzunel M, Ringden O: Treatment of severe acute graft-versus-host disease with third party haploidentical mesenchymal stem cells. Lancet 2004, 363:1439-1441.
102. Lin Q: Yun Z Impact of the hypoxic tumor microenvironment on the regulation of cancer stem cell characteristics. Cancer Biol Ther 2010, 9:949-56.

103. Tomé M, López-Romero P, Albo C, Sepúlveda JC, Fernández-Gutiérrez B, Dopazo A, Bernad A, González MA: miR-335 orchestrates cell proliferation, migration and differentiation in human mesenchymal stem cells. Cell Death Differ 2011, 18:985-995.

104. Tavazoie SF, Alarcón C, Oskarsson T, Padua D, Wang Q, Bos PD, Gerald WL, Massagué J: Endogenous human microRNAs that suppress breast cancer metastasis. Nature 2008, 451:147-152

105. Hogan NM, Dwyer RM, Joyce MR, Kerin MJ: Mesenchymal stem cells in the colorectal tumor microenvironment: recent progress and implications. Int J Cancer 2012, 131:1-7.

106. Etienne-Manneville S: Polarity proteins in migration and invasion. Oncogene 2008, 27:6970-6980.

107. Zhu W, Huang L, Li Y, Zhang X, Gu J, Yan Y, Xu X, Wang M, Qian H, Xu W: Exosomes derived from human bone marrow mesenchymal stem cells promote tumor growth in vivo. Cancer Lett 2012, 315:28-37.

108. Gregory LA, Ricart RA, Patel SA, Lim PK, Lim P: microRNAs, Gap Junctional Intercellular Communication and Mesenchymal Stem Cells in Breast Cancer Metastasis. Curr Cancer Ther Rev 2011, 7:176-183.

109. Donahue HJ, Saunders MM, Li Z, Mastro AM, Gay CV, Welch DR: A potential role for gap junctions in breast cancer metastasis to bone. $J$ Musculoskelet Neuronal Interact 2003, 3:156-161.

110. Rameshwar P: Potential novel targets in breast cancer. Curr Pharm Biotechnol 2009, 10:148-153.

111. Roorda BD, Elst A, Boer TG, Kamps WA, de Bont ES: Mesenchymal stem cells contribute to tumor cell proliferation by direct cell-cell contact interactions. Cancer Invest 2010, 28:526-34.

112. Shen Q, Rahn JJ, Zhang J, Gunasekera N, Sun X, Shaw AR, Hendzel MJ, Hoffman P, Bernier A, Hugh JC: MUC1 initiates Src-CrkL-Rac1/Cdc42mediated actin cytoskeletal protrusive motility after ligating intercellular adhesion molecule-1. Mol Cancer Res 2008, 6:555-567.

113. Kufe D, Inghirami G, Abe M, Hayes D, Justi-Wheeler H, Schlom J: Differential reactivity of a novel monoclonal antibody (DF3) with human malignant versus benign breast tumors. Hybridoma 1984, 3:223-232.

114. Rahn JJ, Dabbagh L, Pasdar M, Hugh JC: The importance of MUC1 cellular localization in patients with breast carcinoma: an immunohistologic study of 71 patients and review of the literature. Cancer 2001, 91:1973-1982

115. McGrail DJ, Ghosh D, Quach ND, Dawson MR: Differential mechanical response of mesenchymal stem cells and fibroblasts to tumor-secreted soluble factors. PLoS One 2012, 7:e33248.

116. Gauthaman K, Yee FC, Cheyyatraivendran S, Biswas A, Choolani M, Bongso A: Human umbilical cord Wharton's jelly stem cell (hWJSC) extracts inhibit cancer cell growth in vitro. J Cell Biochem 2012, 113:2027-2039.

117. Ling X, Marini F, Konopleva M, Schober W, Shi Y, Burks J, Clise-Dwyer K, Wang RY, Zhang W, Yuan X, Lu H, Caldwell L, Andreeff M: Mesenchyma Stem Cells Overexpressing IFN- $\beta$ Inhibit Breast Cancer Growth and Metastases through Stat3 Signaling in a Syngeneic Tumor Model. Cancer Microenviron 2010, 3:83-95.

118. Sun B, Yu KR, Bhandari DR, Jung JW, Kang SK, Kang KS: Human umbilical cord blood mesenchymal stem cell-derived extracellular matrix prohibits metastatic cancer cell MDA-MB-231 proliferation. Cancer Lett 2010, 296:178-185.

119. Kim DS, Kim JH, Lee JK, Choi SJ, Kim JS, Jeun SS, Oh W, Yang YS, Chang JW: Overexpression of CXC chemokine receptors is required for the superior glioma-tracking property of umbilical cord blood-derived mesenchymal stem cells. Stem Cells Dev 2009, 18:511-519.

120. Schichor C, Birnbaum T, Etminan N, Schnell O, Grau S, Miebach S, Aboody K, Padovan C, Straube A, Tonn JC, Goldbrunner R: Vascular endothelial growth factor A contributes to glioma-induced migration of human marrow stromal cells (hMSC). Exp Neurol 2006, 199:301-310.

121. Birnbaum T, Roider J, Schankin CJ, Padovan CS, Schichor C, Goldbrunner R, Straube A: Malignant gliomas actively recruit bone marrow stromal cells by secreting angiogenic cytokines. J Neurooncol 2007, 83:241-247.

122. Ries C, Egea V, Karow M, Kolb H, Jochum M, Neth P: MMP-2, MT1-MMP and TIMP-2 are essential for the invasive capacity of human mesenchymal stem cells: differential regulation by inflammatory cytokines. Blood 2007, 109:4055-4063. 
123. Nakamura K, Ito $Y$, Kawano $Y$, Kurozumi K, Kobune M, Tsuda H, Bizen A, Honmou O, Niitsu Y, Hamada $\mathrm{H}$ : Antitumor effect of genetically engineered mesenchymal stem cells in a rat glioma model. Gene Ther 2004, 11:1155-1164.

124. Nakamizo A, Marini F, Amano T, Khan A, Studeny M, Gumin J, Chen J, Hentschel S, Vecil G, Dembinski J, Andreeff M, Lang FF: Human bone marrow-derived mesenchymal stem cells in the treatment of gliomas. Cancer Res 2005, 65:3307-3318.

125. Doucette T, Rao G, Yang Y, Gumin J, Shinojima N, Bekele BN, Qiao W, Zhang W Lang FF: Mesenchymal stem cells display tumor-specific tropism in an RCAS/ Ntv-a glioma model. Neoplasia 2011, 13:716-725.

126. Lai RC, Tan SS, Teh BJ, Sze SK, Arslan F, de Kleijn DP, Choo A, Lim SK: Proteolytic Potential of the MSC Exosome Proteome: Implications for an Exosome-Mediated Delivery of Therapeutic Proteasome. Int J Proteomics 2012, 2012:971907.

127. Yeo RW, Lai RC, Zhang B, Tan SS, Yin Y, Teh BJ, Lim SK: Mesenchymal stem cell: An efficient mass producer of exosomes for drug delivery. Adv Drug Deliv Rev 2012, Epub ahead of print.

128. Reagan MR, Ghobrial IM: Multiple myeloma mesenchymal stem cells: characterization, origin, and tumor-promoting effects. Clin Cancer Res 2012, 18:342-349.

129. Guiducci S, Manetti M, Romano E, Mazzanti B, Ceccarelli C, Dal Pozzo S, Milia AF, Bellando-Randone S, Fiori G, Conforti ML, Saccardi R, IbbaManneschi L, Matucci-Cerinic M: Bone marrow-derived mesenchymal stem cells from early diffuse systemic sclerosis exhibit a paracrine machinery and stimulate angiogenesis in vitro. Ann Rheum Dis 2011, 70:2011-1221.

130. Matushansky I, Hernando E, Socci ND, Mills JE, Matos TA, Edgar MA, Singer $S$, Maki RG, Cordon-Cardo C: Derivation of sarcomas from mesenchymal stem cells via inactivation of the Wnt pathway. J Clin Invest 2007, 117:3248-3257.

131. Røsland GV, Svendsen A, Torsvik A, Sobala E, McCormack E, Immervoll H, Mysliwietz J, Tonn JC, Goldbrunner R, Lønning PE, Bjerkvig R, Schichor C: Long-term cultures of bone marrow-derived human mesenchymal stem cells frequently undergo spontaneous malignant transformation. Cancer Res 2009, 69:5331-5339.

132. Maltman DJ, Hardy SA, Przyborski SA: Role of mesenchymal stem cells in neurogenesis and nervous system repair. Neurochem Int 2011, 59:347-356.

133. Strassburg S, Hodson NW, Hill PI, Richardson SM, Hoyland JA: Bi-directional exchange of membrane components occurs during co-culture of mesenchymal stem cells and nucleus pulposus cells. PLoS One 2012, 7(3): e33739.

134. Lotfi R, Eisenbacher J, Solgi G, Fuchs K, Yildiz T, Nienhaus C, Rojewski MT, Schrezenmeier $\mathrm{H}$ : Human mesenchymal stem cells respond to native but not oxidized damage associated molecular pattern molecules from necrotic (tumor) material. Eur J Immunol 2011, 41:2021-2028.

135. Mishra PJ, Mishra PJ, Humeniuk R, Medina DJ, Alexe G, Mesirov JP, Ganesan S, Glod JW, Banerjee D: Carcinoma-associated fibroblast-like differentiation of human mesenchymal stem cells. Cancer Res 2008 , 68:4331-4339.

136. Rodriguez R, Rubio R, Menendez P: Modeling sarcomagenesis using multipotent mesenchymal stem cells. Cell Res 2012, 22:62-77.

137. Rodríguez R, García-Castro J, Trigueros C, García Arranz M, Menéndez P: Multipotent mesenchymal stromal cells: clinical applications and cancer modeling. Adv Exp Med Biol 2012, 741:187-205.

138. Yan XL, Fu CJ, Chen L, Qin JH, Zeng Q, Yuan HF, Nan X, Chen HX, Zhou JN, Lin YL, Zhang XM, Yu CZ, Yue W, Pei XT: Mesenchymal stem cells from primary breast cancer tissue promote cancer proliferation and enhance mammosphere formation partially via EGF/EGFR/Akt pathway. Breast Cancer Res Treat 2012, 132:153-64.

139. Battula VL, Evans KW, Hollier BG, Shi Y, Marini FC, Ayyanan A, Wang RY, Brisken C, Guerra R, Andreeff M, Mani SA: Epithelial-Mesenchymal Transition-Derived Cells Exhibit Multi-Lineage Differentiation Potential Similar to Mesenchymal Stem Cells. Stem Cells 2010, 28:1435-1445.

140. Hass R, Bertram C: Characterization of human breast cancer epithelial cells (HBCEC) derived from long term cultured biopsies. J Exp \& Clin Cancer Res 2009, 28:127.

141. De Giorgi U, Cohen EN, Gao H, Mego M, Lee BN, Lodhi A, Cristofanilli M, Lucci A, Reuben JM: Mesenchymal stem cells expressing GD2 and CD271 correlate with breast cancer-initiating cells in bone marrow. Cancer Biol Ther 2011, 11:812-815.
142. Korkaya H, Liu S, Wicha MS: Breast cancer stem cells, cytokine networks, and the tumor microenvironment. J Clin Invest 2011, 121:3804-3809.

143. Karnoub AE, Dash AB, Vo AP, Sullivan A, Brooks MW, Bell GW, Richardson AL, Polyak K, Tubo R, Weinberg RA: Mesenchymal stem cells within tumour stroma promote breast cancer metastasis. Nature 2007, 449:557-563.

144. Muñoz-Fernández R, Prados A, Leno-Durán E, Blázquez A, García-Fernández JR, Ortiz-Ferrón G, Olivares EG: Human decidual stromal cells secrete C-X-C motif chemokine 13 , express $B$ cell-activating factor and rescue $B$ lymphocytes from apoptosis: distinctive characteristics of follicular dendritic cells. Hum Reprod 2012, 27:2775-2784.

\section{doi:10.1186/1478-811X-10-26}

Cite this article as: Hass and Otte: Mesenchymal stem cells as all-round supporters in a normal and neoplastic microenvironment. Cell Communication and Signaling 2012 10:26.

\section{Submit your next manuscript to BioMed Central and take full advantage of:}

- Convenient online submission

- Thorough peer review

- No space constraints or color figure charges

- Immediate publication on acceptance

- Inclusion in PubMed, CAS, Scopus and Google Scholar

- Research which is freely available for redistribution

Submit your manuscript at www.biomedcentral.com/submit
C Biomed Central 